\title{
THE TREATY ON THE PROHIBITION OF NUCLEAR WEAPONS: A PROMISE, A THREAT OR A FLOP?
}

\author{
MARCO PEDRAZZI
}

\begin{abstract}
On 7 July 2017 a UN Conference, convened in New York by the General Assembly, adopted a Treaty on the Prohibition of Nuclear Weapons, providing for the first total ban on these weapons intended to be global in scale. The Treaty was opened for signature on 20 September 2017. The process and its outcome, were, however, firmly opposed by nuclearweapon States and by NATO countries, including Italy: they refused to take part in the effort, fearing that it could definitively undermine the stability of the non-proliferation architecture built upon the 1967 Non-Proliferation Treaty. In reality, the Treaty is consistent with the ultimate purpose of the NPT regime, and the obligations assumed by States under the NPT remain untouched. Its main deficiencies relate to its verification apparatus, and it would be advisable to remedy them through future negotiations. Whether this instrument will enter into force is not clear, although it has the potential to acquire, and surpass, the fifty ratifications necessary. However, the absence of support from nuclear-weapon States risks rendering it irrelevant. Nevertheless, it seems plausible that broad support for this new regime, from nonnuclear-weapons States, as well as from civil society, could contribute to exerting pressure towards the adoption of concrete steps in the nuclear disarmament agenda.
\end{abstract}

Keywords: nuclear weapons; weapons of mass destruction; disarmament; nonproliferation; UN General Assembly; UN Security Council; NATO; law of treaties; international humanitarian law.

\section{INTRODUCTION}

A UN General Assembly's resolution of 23 December 2016, ${ }^{1}$ while recalling that the Treaty on the Non-Proliferation of Nuclear Weapons of 1 July $1968^{2}$ (NPT) "serves as the cornerstone of the nuclear non-proliferation and disarmament regime", acted to convene "a United Nations conference to negotiate a legally binding instrument to prohibit nuclear weapons, leading towards their total elimination". The resolution was adopted with 113 votes in favour, 35 against and 13 abstentions. ${ }^{3}$ The conference met in New York from 27 to 31 March and from 15 June to 7 July 2017, on which date the Treaty on the Prohibition of Nuclear Weapons (TPNW) was adopted, with 122 votes in favour, one against (the Netherlands) and one abstention (Singapore). None of the nuclear weapons States, or NATO countries (except the Netherlands), or other "nuclear umbrella States", such as Australia, Japan and South Korea, took part in the Conference, however. The Treaty was opened for

\footnotetext{
* Professor of International Law, University of Milan.

${ }^{1}$ UN Doc. A/RES/71/258 (2017).

2 Treaty on the Non-proliferation of Nuclear Weapons, 1 July 1968, entered into force 5 March 1970.

${ }^{3}$ However, "[s]ubsequently, the delegations of Albania, Estonia and Italy informed the Secretariat that they had intended to vote against; the delegation of the Comoros had intended to abstain": see UN Doc.
} A/71/PV.68 (2016), p. 17. 
signature at the UN headquarters on 20 September 2017. It will enter into force after the number of ratifications reaches fifty, according to its Article 15.

The following analysis will briefly trace the origins of the Treaty; it will delineate its structure and main contents, comparing them with other, similar conventional regimes; it will deal with its relationship with the non-proliferation regime, which is the main bone of contention; it will outline the Italian position on this instrument; and it will conclude with a tentative assessment of the prospects for its entry into force and its future universalisation.

\section{The Origins OF the TREATY: The HumanitARIAN INITIATIVE}

The origins of the TPNW can be tracked to the deep dissatisfaction of various nonnuclear-weapon States with what they perceive to be a substantial lack of implementation of Article VI NPT, one of the Treaty's three pillars, which obliges all States Parties to engage in serious disarmament efforts. ${ }^{4}$ The International Court of Justice clarified the nature of this obligation in its Advisory Opinion on the Legality of the Threat or Use of Nuclear Weapons in the following terms:

The legal import of that obligation goes beyond that of a mere obligation of conduct; the obligation involved here is an obligation to achieve a precise result nuclear disarmament in all its aspects - by adopting a particular course of conduct, namely, the pursuit of negotiations on the matter in good faith. ${ }^{5}$

Undoubtedly, in the close to fifty years since the NPT entered into force in 1970, overall nuclear arsenals have been reduced, in particular on the basis of a series of agreements between the two nuclear superpowers, the US on one side, and the USSR and later Russia on the other side. ${ }^{6}$ There has also been progress in relation to nuclear weapon tests, a moratorium on which has been respected by all States for decades notwithstanding the non-entry into force of the Comprehensive Nuclear-Test-Ban Treaty (CTBT), ${ }^{7}$ with the notable exception of North Korea. However, while some new de facto nuclear-weapon States have proliferated outside the NPT framework, or after having rejected that framework (as in the case of North Korea), other, de jure nuclear-weapon States have continued to increase their stockpiles, and several of them are proceeding with the modernization of their arsenals, whose destructive

${ }^{4}$ Art. VI NPT reads as follows: "Each of the Parties to the Treaty undertakes to pursue negotiations in good faith on effective measures relating to cessation of the nuclear arms race at an early date and to nuclear disarmament, and on a Treaty on general and complete disarmament under strict and effective international control". See, inter alia, FLECK, International Law Association Committee on Nuclear Weapons, NonProliferation and Contemporary International Law, "Second report, Legal Aspects of Nuclear Disarmament", 2014, available at: <http://www.ila-hq.org/index.php/committees>; RosCINI, "On Certain Legal Issues Arising from Article VI of the Treaty on the Non-Proliferation of Nuclear Weapons", in CARACCIOLO, PEDRAZZI and VASSAlli Di Dachenhausen (eds.), Nuclear Weapons: Strengthening the International Legal Regime, The Hague, 2016, p. 15 ff.; MAGI, "L'obbligo di disarmo nucleare quale obbligo a realizzazione progressiva", RDI, 2018, p. $58 \mathrm{ff}$.

${ }^{5}$ Legality of the Threat or Use of Nuclear Weapons, Advisory Opinion of 8 July 1996, ICJ Reports, 1996, p. $226 \mathrm{ff}$., para. 99

${ }^{6}$ See the data reproduced in CORRALES, "Tratado sobre la prohibición de las armas nucleares: ¿avance hacia el desarme nuclear?", Instituto Español de Estudios Estratégicos, Opinión, available at: $<$ http://www.ieee.es/publicaciones-new/documentos-de-opinion/2017/DIEEEO97-2017.html>, p. 6-9.

7 Comprehensive Nuclear-Test-Ban Treaty, 10 September 1996, not entered into force, available at: $<$ http://disarmament.un.org/treaties/t/ctbt/text $>$. 
potential has progressively grown over time. ${ }^{8}$ Overall, the prospects for nuclear disarmament do not seem much better today than they did in 1968, when the NPT was adopted.

The NPT review conferences did little to improve these prospects, notwithstanding the hopes raised by the Programme of Action agreed to in 1995, ${ }^{9}$ the 13-point plan decided in $2000,{ }^{10}$ and, after the 2005 conference's failure, the 64-point Action Plan issued in 2010. ${ }^{11}$

It is also worth recalling that the attempts to obtain authoritative judicial pronouncements "outlawing" nuclear weapons on the basis of their presumed unlawfulness under general international law have failed. The ICJ, in its identical 1974 judgments in the Nuclear Tests cases (Australia v. France and New Zealand v. France) did not pronounce on the merits of the claims (the two countries had asked the Court to declare the illegality of further French nuclear tests in the South Pacific and to order France not to proceed with such tests). Instead, the Court held that France's unilateral declaration announcing the end of its atmospheric tests in the Pacific was a legal undertaking which deprived the parties' claims of their object. ${ }^{12}$ In its 1996 Advisory Opinion, the Court, while recognizing that "the threat or use of nuclear weapons would generally be contrary to the rules of international law applicable in armed conflict, and in particular the principles and rules of humanitarian law", left the door open to a possible instance of lawfulness of such threat or use "in an extreme circumstance of self-defence, in which the very survival of a State would be at stake". ${ }^{13}$ Finally, in its recent judgments on the claims brought by the Marshall Islands against the UK, India and Pakistan relating to the alleged violation of Article VI NPT, or of the assumed corresponding norm of customary international law, the Court found that it lacked jurisdiction due to the absence of a legal dispute among the parties. ${ }^{14}$

The driving force behind the move towards the Humanitarian Initiative was a clause that was inserted in the Final document of the NPT 2010 Review Conference, which pointed to "the catastrophic humanitarian consequences that would result from the use of nuclear weapons". ${ }^{15}$ In addition, in 2011, the Council of Delegates of the International Red Cross and Red Crescent Movement stated in a resolution that it found "difficult to envisage how any use

${ }^{8}$ See, inter alia, US Department of Defense, "Nuclear Posture Review February 2018", Executive Summary, available at $<$ https://www.defense.gov/News/SpecialReports/2018NuclearPostureReview.aspx $>$, and Russian president Putin's response in his state of the nation speech of 1 March 2018 (see "Putin's 'Invincible' Missile is Aimed at U.S. Vulnerabilities", The New York Times, available at: $<$ https://www.nytimes.com/2018/03/01/world/europe/russia-putin-speech.html>).

${ }^{9}$ Final Document of the 1995 Review and Extension Conference of the Parties to the Treaty on the NonProliferation of Nuclear Weapons, NPT/CONF.1995/32 (Part I), Annex, Decision 2.

${ }^{10}$ Final Document of the 2000 Review Conference of the Parties to the Treaty on the Non-Proliferation of Nuclear Weapons, NPT/CONF.2000/28 (Parts I and II), para. 15.

${ }^{11}$ Final Document of the 2010 Review Conference of the Parties to the Treaty on the Non-Proliferation of Nuclear Weapons, NPT/CONF.2010/50 (Vol. I), p. 19 ff. For a brief survey, see FANIELLE, "Towards Nuclear Disarmament: State of Affairs in the International Legal Framework”, Nuclear Law Bulletin, 2016, p. 35 ff, pp. 42-43.

${ }^{12}$ Nuclear Tests (Australia v. France), Judgment of 20 December 1974, ICJ Reports, 1974, p. 253 ff., paras. 42 ff.; Nuclear Tests (New Zealand v. France), Judgment of 20 December 1974, ICJ Reports, 1974, p. 457 ff., paras. $45 \mathrm{ff}$.

${ }^{13}$ Legality of the Threat or Use of Nuclear Weapons, cit. supra note 5, para. 105(E).

14 Obligations concerning negotiations relating to cessation of the nuclear arms race and to nuclear disarmament (Marshall Islands v. United Kingdom), Preliminary objections, Judgment of 5 October 2016, ICJ Reports, 2016, p. 833 ff., paras. 36 ff.; Obligations concerning negotiations relating to cessation of the nuclear arms race and to nuclear disarmament (Marshall Islands v. India), Preliminary objections, Judgment of 5 October 2016, ICJ Reports, 2016, p. 255 ff, paras. 33 ff.; Obligations concerning negotiations relating to cessation of the nuclear arms race and to nuclear disarmament (Marshall Islands v. Pakistan), Preliminary objections, Judgment of 5 October 2016, ICJ Reports, 2016, p. 552 ff., paras. 33 ff.

152010 Review Conference, cit. supra note 11, para. 80: "The Conference expresses its deep concern at the continued risk for humanity represented by the possibility that these weapons could be used and the catastrophic humanitarian consequences that would result from the use of nuclear weapons". 
of nuclear weapons could be compatible with the rules of international humanitarian law, in particular the rules of distinction, precaution and proportionality". The resolution also appealed to all States "to pursue in good faith and conclude with urgency and determination negotiations to prohibit the use of and completely eliminate nuclear weapons through a legally binding international agreement". ${ }^{16}$ On these bases, a Group of 16 States Parties to the NPT took a firm stand on the "humanitarian dimension of nuclear disarmament", calling for further decisive steps during the 2012 Prep Com for the 2015 Review Conference. ${ }^{17}$ Contemporaneously, Norway, the only NATO member country in the group, called for a conference in spring 2013, "to highlight the humanitarian consequences of nuclear weapons, including the incompatibility of their use under international humanitarian law (IHL)". ${ }^{18}$ The Oslo International Conference on the Humanitarian Impact of Nuclear Weapons of 4 and 5 March 2013 was followed by two further conferences in Nayarit, Mexico, on 13 and 14 February 2014, and in Vienna, on 8 and 9 December 2014. They enjoyed broad participation by states, UN bodies, the International Red Cross and Red Crescent Movement and a number of NGOs active in the fight for the elimination of all nuclear arsenals. The process was initially boycotted, however, by the big five: only the UK and the US decided to participate in the final conference in Vienna. The conferences' agenda focused on the dire humanitarian consequences of the use of nuclear weapons on people, the environment and society at large; on the impossibility to provide adequate humanitarian responses to face such consequences; and on the risks that the mere presence of nuclear arsenals entail for the possible accidental outbreak of nuclear war. Their ultimate purpose was clearly to pursue the definitive outlawing of nuclear weapons: the "Austrian pledge", issued at the closure of the Vienna conference, indicated that country's commitment "to cooperate with all relevant stakeholders [...] in efforts to stigmatise, prohibit and eliminate nuclear weapons in light of their unacceptable humanitarian consequences and associated risks". ${ }^{19}$ After the failure of the 2015 NPT Review Conference, the "humanitarian pledge" was incorporated in a UN General Assembly resolution approved by 139 Member States. ${ }^{20}$ This outcome was not acceptable to the nuclear powers and their allies.

Simultaneously, the General Assembly decided to convene an open-ended working group "to substantively address concrete effective legal measures, legal provisions and norms that will need to be concluded to attain and maintain a world without nuclear weapons". ${ }^{21}$ In its final report issued in 2016, the open-ended working group recommended "the convening, by the General Assembly, of a conference in 2017, open to all States, with the participation and contribution of international organizations and civil society, to negotiate a legally binding instrument to prohibit nuclear weapons, leading towards their total elimination". ${ }^{22}$ This led to

16 "Working towards the elimination of nuclear weapons", 26 November 2011, available at: $<$ https://www.icrc.org/eng/resources/documents/resolution/council-delegates-resolution-1-2011.htm>.

${ }^{17}$ See First Session of the Preparatory Committee for the 2015 Review Conference of the Parties to the Treaty on the Non-Proliferation of Nuclear Weapons, Statement of Switzerland on behalf of States parties focusing on The Humanitarian Dimension, 2 May 2012, available at: $<$ https://www.un.org/disarmament/wmd/nuclear/npt2015/prepcom2012-statements/>. The Group included the following States: Austria, Chile, Costa Rica, Denmark, Holy See, Egypt, Indonesia, Ireland, Malaysia, Mexico, New Zealand, Nigeria, Norway, Philippines, South Africa, Switzerland.

18 See ibid., Statement of Norway, 30 April 2012. See also KMENTT, "The Development of the International Initiative on the Humanitarian Impact of Nuclear Weapons and its Effects on the Nuclear Weapons Debate", IRRC, 2015, p. 681 ff., p. 683.

19 More information is available at: <https://www.bmeia.gv.at/en/european-foreignpolicy/disarmament/weapons-of-mass-destruction/nuclear-weapons-and-nuclear-terrorism/vienna-conferenceon-the-humanitarian-impact-of-nuclear-weapons/->.

${ }^{20}$ UN Doc. A/RES/70/48 (2015): the resolution met 29 votes against and 17 abstentions.

${ }^{21}$ UN Doc. A/RES/70/33 (2015), adopted with 138 votes in favour, 12 against and 34 abstentions.

${ }^{22}$ UN Doc. A/71/371 (2016), para. 67. 
the abovementioned General Assembly resolution convening the New York conference for the negotiation of the Treaty.

\section{The New York Conference, the Adoption of the Treaty, And its Purpose And STRUCTURE}

The United Nations Conference to Negotiate a Legally Binding Instrument to Prohibit Nuclear Weapons, Leading Towards their Total Elimination opened in New York on 27 March 2017. The Conference saw the participation of 125 States, the Agency for the Prohibition of Nuclear Weapons in Latin America and the Caribbean (OPANAL), the European Union, the International Committee of the Red Cross (ICRC) and the International Federation of Red Cross and Red Crescent Societies (IFRC), the Inter-Parliamentary Union and the UN Institute for Disarmament Research (UNIDIR). NGOs also actively participated in the conference, producing a relevant number of documents: among these, the proposals produced by the disarmament programme (Reaching Critical Will) of the Women's International League for Peace and Freedom, a member of the International Campaign to Abolish Nuclear Weapons (ICAN), are worth mentioning. ${ }^{23}$ The crucial role played by NGOs in the whole process, starting with the Humanitarian Initiative and ending with the TPNW, led ICAN to earn the 2017 Nobel peace prize. ${ }^{24}$

The purpose of the Treaty is clearly enunciated in the second indent of its Preamble, whereby the drafters, based on their deep concern for "the catastrophic humanitarian consequences that would result from any use of nuclear weapons", affirm the "need to completely eliminate such weapons", as "the only way to guarantee that nuclear weapons are never used again under any circumstances". In conformity with this stated purpose, the TPNW is both a disarmament and an international humanitarian law instrument, providing on one side for the total elimination of nuclear weapons, on the other side for an absolute ban on their use. The Treaty's nature is therefore comparable to that of such instruments as the 1993 Chemical Weapons Convention (CWC), ${ }^{25}$ the 1997 Anti-Personnel Mine Ban Convention $(\mathrm{APMC})^{26}$ and the 2008 Cluster Munitions Convention (CMC). ${ }^{27}$ At the same time, the TPNW completes the circle of instruments pursuing the total outlawing of all weapons of mass destruction (WMD), adding to the already mentioned CWC and to the 1972 Biological Weapons Convention (BWC), which, from a formal point of view, is merely a disarmament treaty, as it does not contain an explicit ban on use. ${ }^{28}$ From another perspective, we may say that the Treaty aims to universalize the bans already established at the regional level, albeit

23 See ACHESON, "Banning Nuclear Weapons. Principles and Elements for a Legally Binding Instrument", March 2017, and ID., "Banning Nuclear Weapons. Prohibitions for a Nuclear Weapon Ban Treaty", June 2017, both available at: <http://www.reachingcriticalwill.org/resources/publications-and-research/researchprojects/9146-banning-nuclear-weapons>.

24 ICAN was awarded the prize "for its work to draw attention to the catastrophic humanitarian consequences of any use of nuclear weapons and for its ground-breaking efforts to achieve a treaty-based prohibition of such weapons". The explanation of the prize is available at: $<$ https://www.nobelprize.org/nobel_prizes/peace/laureates/2017/ican-facts.html>.

${ }^{25}$ Convention on the Prohibition of the Development, Production, Stockpiling and Use of Chemical Weapons and on their Destruction, 13 January 1993, entered into force 29 April 1997.

${ }^{26}$ Convention on the Prohibition of the Use, Stockpiling, Production and Transfer of Anti-Personnel Mines and on their Destruction, 18 September 1997, opened for signature 3 December 1997, entered into force 1 March 1999.

27 Convention on Cluster Munitions, adopted 30 May 2008, opened for signature 3 December 2008, entered into force 1 August 2010.

${ }^{28}$ Convention on the Prohibition of the Development, Production and Stockpiling of Bacteriological (Biological) and Toxin Weapons and on their Destruction, 10 April 1972, entered into force 26 March 1975. 
with different degrees of amplitude and nuances, by the treaties establishing nuclear weapon free zones (NWFZ). ${ }^{29}$

The text of the Treaty contains a long preamble and 20 articles. The core obligations are spelled out in Article 1. The subsequent articles deal with the crucial issue of verification and control, establishing diversified requirements in relation to the different positions of States Parties. Article 5 deals with national implementation and articles 6 and 7 with assistance and remediation. Article 8 inaugurates the procedural part of the Treaty, followed by the final clauses. The TPNW's structure is similar to, although simpler than, that of the CWC, the $\mathrm{APMC}$ and the $\mathrm{CMC}$, as the following paragraph will demonstrate.

\section{The Contents of the Treaty: The Disarmament Obligations; Duration and WITHDRAWAL}

As mentioned above, Article 1 is the core of the Treaty, as it traces the fundamental obligations falling on States Parties. The formulations are more detailed than those contained in the CWC, the APMC or the CMC, recalling the provisions of the Pelindaba and Semipalatinsk treaties. In substance, the provisions impose on all States Parties to abstain from any act entailing the opportunity to acquire or receive or develop nuclear weapons or other nuclear explosive devices, to possess or stockpile or test them, to transfer them to any entity, to use or threaten the use of such devices, to assist any entity in one of the abovementioned activities, and to allow them to be stationed at any place under their jurisdiction. The provision is clearly all-encompassing, as no exception is contemplated that would entail the admittance of the prohibited items in any State Party under any form.

Some points deserve clarification. A striking difference with respect to most other weapons treaties is the absence of definitions: in particular, "nuclear weapons" and "other nuclear explosive devices" remain devoid of any legal definition. By contrast, not only are other weapons, such as chemical ones, anti-personnel mines and cluster munitions, defined in detail in their respective instruments, but the nuclear weapons themselves are defined in the NWFZ treaties. E.g., under the Semipalatinsk Treaty, " [n] uclear weapon or other nuclear explosive device' means any weapon or other explosive device capable of releasing nuclear energy, irrespective of the military or civilian purpose for which the weapon or device could be used". ${ }^{30}$ At the New York Conference, Sweden proposed the introduction of a definition, ${ }^{31}$

${ }^{29}$ See Treaty for the Prohibition of Nuclear Weapons in Latin America and the Caribbean (so-called Treaty of Tlatelolco), 14 February 1967, entered into force 25 April 1969; South Pacific Nuclear Free Zone Treaty, 6 August 1985, entered into force 11 December 1986; Treaty on the Southeast Asia Nuclear WeaponFree Zone, 15 December 1995, entered into force 27 March 1997; African Nuclear Weapon Free Zone Treaty (so called Treaty of Pelindaba), 11 April 1996, entered into force on 15 July 2009; Treaty on a Nuclear-WeaponFree Zone in Central Asia, 8 September 2006, entered into force 21 March 2009. Nuclear weapons are also banned by the Antarctic Treaty, 1 December 1959, entered into force 23 June 1961, and by the Outer Space Treaty, 27 January 1967, entered into force 10 October 1967, from, respectively, Antarctica and outer space (including the Moon and other celestial bodies), and Mongolia, on the basis of a unilateral declaration. For a general analysis, see RoscinI, Le zone denuclearizzate, Torino, 2003.

${ }^{30}$ Art. 1(b). The norm continues specifying: "The term includes such a weapon or device in unassembled or partly assembled forms, but does not include the means of transport or delivery of such a weapon or device if separable from and not an indivisible part of it".

31 See UN Doc. A/CONF.229/2017/WP.5 (2017). All documents of the New York Conference are available at: $<$ https://www.un.org/disarmament/ptnw/index.html $>$. The proposal was quite controversial, as it referred to "[weapon] assembly that is capable of producing an explosion and massive damage and destruction by the sudden release of energy instantaneously released from self-sustaining nuclear fission and/or fusion" (emphasis added). More generally, on the absence of any definition see also the comment of the Netherlands on Art. 1 of the Draft, in Compilation of amendments received from States on the revised draft submitted by the President dated 30 June 2017, UN Doc. A/CONF.229/2017/CRP.1/Rev.1 (2017). 
but the proposal was not accepted. In fact, the lack of a definition also characterizes the NPT, without prejudicing its interpretation and application: it was evidently felt that a clearly accepted meaning already exists, thanks in part to the supervisory functions performed by the IAEA under the safeguards agreements.

The all-encompassing Article 1 prohibitions include the ban on allowing the stationing or deployment of any nuclear weapons or nuclear explosive devices on the State Parties' territory. As is well known, no such ban is explicitly spelled out in the NPT's text, giving way to opposing views on the legitimacy of the position of non-nuclear-weapon States, such as Italy, Belgium, Germany, the Netherlands and Turkey, which host on their territory US nuclear weapons, under US control (but subject to local consent in case of use, according to a "double key" system). ${ }^{32}$ Now, for the first time, a rule banning nuclear sharing arrangements is being explicitly posed at the universal level.

In line with its purpose, the Treaty "is of unlimited duration" (Article 17(1)). Nonetheless, as with all disarmament treaties, the TPNW contains a withdrawal clause, according to which, as usual, a State party has the right to withdraw "if it decides that extraordinary events related to the subject matter of the Treaty have jeopardized" its "supreme interests." Furthermore, the withdrawal notice "shall include a statement" of such "extraordinary events" (Article 17(2)). ${ }^{33}$ The clause is innovative, however, inasmuch as it extends the notice period to up to twelve months and because it provides that if, after the expiration of this period, the State Party is a party to an armed conflict, it "shall continue to be bound by the obligations of the Treaty [...] until it is no longer party to an armed conflict" (Article 17(3)). The restriction in question, whatever its practical effect, is commendable, and providing a possibility of withdrawal was probably unavoidable. All the same, the consistency of such a provision in a treaty bound to totally eliminate a weapon considered radically unlawful (see below) may be called into question. It is further regrettable that the clause does not include a caveat, similar to that enunciated in Article XVI CWC, stating that the withdrawal of a State party "shall not in any way affect the duty of States to continue fulfilling the obligations assumed under any relevant rules of international law". ${ }^{34}$

\section{THE BAN ON THE USE OF NUClEAR WEAPONS AND INTERNATIONAL HUMANitARian LAW}

As previously mentioned, Article 1 also contains a fundamental international humanitarian law provision, banning any use or threat to use nuclear weapons or other nuclear explosive devices: the ban, qualified by the initial clause "never under any circumstances" obviously applies in any kind of armed conflict (and outside any conflict) and includes a ban on reprisals. ${ }^{35}$ These prohibitions are the direct consequence of the statements included in the Preamble, according to which, "any use of nuclear weapons would be contrary to the rules of international law applicable in armed conflict, in particular the principles and rules of

32 On this point, see ALBERQUE, "The NPT and the Origins of NATO's Nuclear Sharing Arrangements", Etudes de l'IFRI, Poliferation Papers No. 57, 2017, available at: $<$ https://www.ifri.org/sites/default/files/atoms/files/alberque_npt_origins_nato_nuclear_2017.pdf $>$.

${ }^{33}$ See similar formulations, inter alia, in Article X NPT; $\bar{A}$ rticle XVI CWC; Article IX CTBT. Generally, see, among others, PONTI, "Il recesso dai trattati in materia di disarmo. Il caso della Corea del nord e il futuro del regime di non proliferazione nucleare", in BATSANOV et al., The Challenges of Disarmament and NonProliferation, Milano, 2007, p. $79 \mathrm{ff}$.

${ }^{34}$ Indeed, see the proposal of New Zealand to this end, in Compilation of amendments, cit. supra note 31.

35 The text does not contain the prohibition "to engage in any military preparations to use" nuclear weapons, as included in the CWC, Art. I(1)(c), although the insertion of such a rule was proposed: see ICRC comments in UN Doc. A/CONF.229/2017/CRP.2 (2017). 
international humanitarian law", and "any use of nuclear weapons would also be abhorrent to the principles of humanity and the dictates of public conscience", in total disregard for the Martens' clause precepts. ${ }^{36}$ These strong positions represent a step further with respect to the cautious attitude followed by the ICJ in its 1996 Advisory Opinion, pointing to the conviction, shared by many States, in line with ICRC views, ${ }^{37}$ that nuclear weapons are already prohibited under international customary law. This is important testimony of opinio juris coming from the majority of the international community, although its relevance is diminished by the fact that it is not supported by the weighty minority of nuclear-weapon States.

\section{VERIFICATION}

With regard to the prohibitions relating to the manufacture, possession and transfer of nuclear weapons and other nuclear explosive devices under Article 1, verification is obviously the core issue. The TPNW's verification system is simpler than that provided by the CWC, but more complex than the ones established by the APMC or the CMC. Its complexities are due to the fact that ratification of the Treaty is open to four different categories of States: 1) States that have never possessed or hosted nuclear weapons; 2) States that have possessed nuclear weapons, and eliminated them before the entry into force of the TPNW for them; 3 ) States that still possess, own or control nuclear weapons; 4) States hosting in their territory nuclear weapons or other nuclear explosive devices under the control of other States. States Parties are to submit to the UN Secretary General, as soon as they ratify the Treaty, a declaration stating their precise position (Article 2). Two different kinds of verification are therefore necessary, as, according to the situation, controls shall verify either the mere nondiversion from peaceful to military uses of nuclear energy or, in addition, the effective dismantling of existing nuclear arsenals. Differently from the CWC, the TPNW does not create, at least for the moment, any new international organization, but mostly relies on existing mechanisms, i.e. on those belonging to the IAEA.

In fact, as a general rule, States Parties "shall, at a minimum, maintain" their IAEA safeguards obligations in force at the time of entry into force of the TPNW. If they are not yet party to any such agreement, they shall conclude with the IAEA, and bring into force, a comprehensive safeguards agreement (INFCIRC/153 (Corrected)) (Article 3). ${ }^{38}$ However, States Parties that have owned, possessed or controlled nuclear weapons or other nuclear explosive devices "after 7 July 2017 ", i.e. after the date of the adoption of the Treaty, but have eliminated their nuclear-weapon programme before the entry into force of the TPNW for them, and States Parties still owning, possessing or controlling such devices are subject to separate mechanisms and obligations under Article 4. The latter "shall immediately remove" such items "from operational status" and destroy them according to "a legally binding, timebound plan" (Paragraph 2). The "irreversible elimination of nuclear-weapons programmes"

${ }^{36}$ See also the ninth indent of the Preamble, referring to "the principle that the right of parties to an armed conflict to choose methods or means of warfare is not unlimited, the rule of distinction, the prohibition against indiscriminate attacks, the rules on proportionality and precautions in attack, the prohibition on the use of weapons of a nature to cause superfluous injury or unnecessary suffering, and the rules for the protection of the natural environment". For a recent consideration of nuclear disarmament under the lens of humanitarian law and human rights law, see RIETIKER, Humanization of Arms Control: Paving the Way for a World Free of Nuclear Weapons, Abingdon, 2017.

${ }^{37}$ See ICRC comments, cit. supra note 35.

${ }^{38}$ For a general survey of the different safeguards agreements see RoCKWOOD, "Legal Framework for IAEA Safeguards", 2013, available at: $<$ https://www.iaea.org/sites/default/files/16/12/legalframeworkforsafeguards.pdf $>$. 
shall be negotiated and verified by a "competent international authority" to be designated by the States Parties (Paragraph 6). ${ }^{39}$ The designation of such an authority and, therefore, the definition of the contours of this second tier of the verification system was evidently postponed, on the basis of an easy prediction that the time for putting it into effect was not imminent... In any case, the same international authority is also to be entrusted with the task of verifying the irreversible elimination of the nuclear-weapon programmes of the former States Parties (Paragraph 1). In addition to that, both categories of States Parties shall conclude with the IAEA a safeguards agreement "sufficient to provide credible assurance of the non-diversion of declared nuclear material from peaceful nuclear activities and of the absence of undeclared nuclear material or activities" in such States "as a whole" (Paragraphs 1 and 3). In this case a clear reference is being made to the Additional Protocols (INFCIRC/540 (Corr.)), the only instruments allowing IAEA to confirm the 'completeness' of States' declarations. ${ }^{40}$

As for States Parties hosting in their territory nuclear weapons owned, possessed or controlled by others, they "shall ensure the prompt removal of such weapons, as soon as possible but not later than a deadline to be determined by the first meeting of States Parties" (Article 4, Paragraph 4).

\section{NATIONAL IMPLEMENTATION, ASSISTANCE AND INTERNATIONAL COOPERATION}

All States Parties are also bound to take all legal and administrative measures to implement the Treaty in their national legal order, including the imposition of penal sanctions to prevent and suppress prohibited activities undertaken by persons or on territory under their jurisdiction or control (Article 5). This provision is important, if rather general.

The provisions on victim assistance (Article 6) and on international cooperation and assistance (Article 7) are inspired in particular by the corresponding articles of the CCM (articles 5 and 6), although they are less developed. Notable aspects of these provisions include the addition to the obligation of the affected State to provide "age-and gendersensitive assistance, without discrimination, including medical care, rehabilitation and psychological support" to victims of use or testing of nuclear weapons, of the duty to take "appropriate measures towards the environmental remediation" of the contaminated areas (Article 6); and the devising of a specific responsibility of the State party that has used or tested such weapons "to provide adequate assistance to affected States Parties", "[w]ithout prejudice to any other duty or obligation that it may have under international law". Since such use or testing would be unlawful under the Treaty, this obligation particularly adds to the content of the international responsibility of the State in question towards the affected States.

\section{THE RELATIONSHIP WITH OTHER INTERNATIONAL AGREEMENTS, INCLUDING THE NPT}

A core aspect of the TPNW, and one that will be crucial for its future prospects, regards its relationship with other international agreements, in particular with the NPT, with which it

${ }^{39}$ According to JOYNER, "My Impressions on the Second Draft of the NW Ban Treaty", Arms Control Law, 28 June 2017, available at: <https://armscontrollaw.com/2017/06/28/my-impressions-on-the-second-draftof-the-nw-ban-treaty/>, it is fortunate that IAEA was assigned the role of "administrator of safeguards agreements" and not the very different one of "presumptive verifier of nuclear weapons disarmament".

${ }^{40}$ See, inter alia, DUPONT, "Interpretation of Nuclear Safeguards Commitments: The Role of Subsequent Agreements and Practice", in BLACK-BRANCH and FLECK (eds.), Nuclear Non-Proliferation in International Law, Volume II. Verification and Compliance, The Hague, 2016, p. 23 ff., p. 24. 
has multiple ties. It is, therefore, not astonishing that many of the critiques of the Treaty focus on these relations. ${ }^{41}$ The matter is regulated by Article 18 of the Treaty, which reads:

The implementation of this Treaty shall not prejudice obligations undertaken by States Parties with regard to existing international agreements, to which they are party, where those obligations are consistent with the Treaty.

This is not an uncommon type of conflict clause: it clearly establishes the prevalence of obligations undertaken under the Treaty over those contracted on the basis of any other previous international agreement, among States parties to both instruments, inasmuch as there is incompatibility between the two sets of obligations. Such a provision is, in fact, unnecessary, in light of Article 30(4)(a) of the Vienna Convention on the Law of Treaties, according to which when the parties to a later treaty do not coincide with the parties to an earlier one, relating to the same subject-matter, ${ }^{42}$ as between States parties to both "the earlier treaty applies only to the extent that its provisions are compatible with those of the later treaty", in conformity with the lex posterior principle. As agreed within the International Law Commission, such a principle would undoubtedly apply when dealing with two treaties belonging to the same legal regime, like the NPT and the TPNW. ${ }^{43}$

The earlier draft of the Treaty provided a different conflict rule, establishing that it did "not affect the rights and obligations under the Treaty on the Non-Proliferation of Nuclear Weapons". "However, as the ICRC pointed out, the proposed norm did not consider the relations with international agreements other than the NPT, and, furthermore, it could "be interpreted as allowing a State Party to the NPT that possesses nuclear weapons to join the convention on the prohibition of nuclear weapons and retain its nuclear weapons, arguing that they have the "right" to do so under the NPT". ${ }^{45}$ Therefore, the ICRC suggested a formulation similar to that which was finally adopted, although according to the ICRC proposal the Treaty would have prevailed over "future", as well as over "existing" international agreements. ${ }^{46}$ This proposal was, in fact, inserted in the second draft treaty submitted at the end of June, ${ }^{47}$ but the term "future" was later deleted.

${ }^{41}$ See the analysis of SOSSAI, "Il rapporto tra il Trattato sul divieto di armi nucleari e gli altri accordi in materia di non proliferazione e disarmo", RDI, 2018, p. 185 ff., p. 192 ff.

42 On the concept, see KOSKENNIEMI, Report of the Study Group of the International Law Commission on Fragmentation of International Law: Difficulties arising from the diversification and expansion of International Law, UN Doc. A/CN.4/L.682 (2006), paras. $21 \mathrm{ff}$.

${ }^{43}$ See International Law Commission, Fragmentation of International Law: Difficulties arising from the Diversification and Expansion of International Law, UN Doc. A/61/10, YILC, 2006, Vol. II, Part II, para. 26, where it is stated that " $[\mathrm{t}]$ he lex posterior principle is at its strongest in regard to conflicting or overlapping provisions that are part of treaties that are institutionally linked or otherwise intended to advance similar objectives (i.e. form part of the same regime)" (emphasis added). See, similarly, SoSSAI, cit. supra note 41, p. 197. According to MASLEN, "The Relationship of the 2017 Treaty on the Prohibition of Nuclear Weapons with other Agreements: Ambiguity, Complementarity or Conflict?”, EJIL: Talk!, 1 August 2017, available at: <https://www.ejiltalk.org/the-relationshipof-the-2017-treaty-on-the-prohibition-of-nuclear-weapons-with-other-agreements-ambiguity-complementarity-orconflict/>, "[i]n some ways, the provision in Art. 18 is little more than a statement of common sense".

44 See Draft Convention on the Prohibition of Nuclear Weapons, submitted by the president of the Conference, Art. 19, UN Doc. A/CONF.229/2017/CRP.1 (2017).

45 On this last point see also JOYNER, "Amicus Memorandum to the Chair of the United Nations Negotiating Conference for a Convention on the Prohibition of Nuclear Weapons", Arms Control Law, 12 June 2017, available at: <https://armscontrollaw.files.wordpress.com/2017/06/amicus-memorandum.pdf $>$.

${ }^{46}$ See ICRC comments, cit. supra note 35 . The proposed clause was in fact the same as that contained in the Arms Trade Treaty, 3 June 2013, entered into force 24 December 2014, Art. 26(1).

${ }^{47}$ See Draft Treaty on the Prohibition of Nuclear Weapons, submitted by the president of the Conference, Art. 19, UN Doc. A/CONF.229/2017/CRP.1/Rev.1 (2017). The proposed formulation attracted the criticisms of some delegations. In particular, according to the Dutch delegation, it would have taken away "flexibility to 
As for future treaties, the deletion of the mention of "future" agreements in Article 18 does not alter the fact that the conclusion by one or more States Parties to the TPNW of an agreement providing for less extensive disarmament obligations than the TPNW (e.g., the long-planned fissile material cut-off treaty), ${ }^{48}$ could never prejudice the stiffer obligations undertaken by States Parties under the TPNW (see also Article 30(5) and Article 41(1)(b), Vienna Convention on the Law of Treaties). The prohibition of reservations, under Article 16, TPNW, is another clear sign that the parties are clearly not allowed to restrict, by any means, the assumption of their obligations under the Treaty. ${ }^{49}$ Thus, the only possibility for replacing the TPNW regime with a more permissive regime would be to form a new agreement involving all the parties to the TPNW.

As the ICRC observed, potential conflicts could also arise in relation to international agreements different from the NPT, specifically with the NWFZ treaties and with the CTBT. In particular, if credit is given to the declaration of Cuba appended to its ratification of the Treaty, according to which the prohibition under Article 1(a), TPNW, "encompasses all forms of testing, including those performed using non-explosive methods such as subcritical testing and computer simulation", 50 the TPNW would establish a broader prohibition on nuclear testing than the CTBT. ${ }^{51}$ This interpretation is debatable however, as proposals from Cuba and others to explicitly include "non-explosive methods" of testing in the prohibition were not accepted. $^{52}$

The main issue that has been raised with regard to testing is, however, the danger that States could be induced to ratify the TPNW without ratifying the CTBT, thus further delaying the entry into force of the latter and of its verification mechanism. ${ }^{53}$ There may be truth to these concerns, but the risk should not be overemphasized. One should recall that, among the ratifications missing from the CTBT are those of some important nuclear powers, which are not likely to ratify the TPNW in the near future, and probably not the CTBT either. Despite this, the CTBT's verification mechanism is already working, to a certain extent, albeit on a provisional basis.

Undoubtedly, the relationship with the NPT is the major bone of contention. The main accusation coming from nuclear powers and NATO Member States is that the TPNW

negotiate future arrangements that could take us further on the path towards global zero [...]" (Compilation of amendments, cit. supra note 31). On the point see SosSAI, cit. supra note 41, p. 195 ff.

48 See KIMBALL and REIF, "Fissile Material Cut-off Treaty (FMCT) at a Glance", Arms Control Association, 18 September 2017, available at: $<$ https://www.armscontrol.org/factsheets/fmct $>$.

${ }^{49} \mathrm{See}$, however, the withdrawal clause, supra Section 4.

${ }^{50}$ Cuba's declaration is available at: $<$ http://disarmament.un.org/treaties/a/tpnw/cuba/rat/un $>$.

${ }^{51}$ Under Art. 1 CTBT, all States parties undertake "not to carry out any nuclear weapon test explosion". See, among others, VENTURINI, "Test-Bans and the Comprehensive Test Ban Treaty Organization", in BLACKBRANCH and FLECK (eds.), Nuclear Non-Proliferation in International Law, Volume I, The Hague, 2014, p. 133 ff., p. 144.

52 See the proposals of Cuba, in Compilation of amendments received from States on the preamble (received as of 29 June), available at: <https://s3.amazonaws.com/unoda-web/wpcontent/uploads/2017/06/Preamble-compilation_REV-2.docx>, and of Iran, in Compilation of amendments, cit. supra note 31 . The current text is at least ambiguous, as the mention of nuclear test "explosions", present in previous drafts, as well as in numerous States' proposals, was deleted, while the CTBT is only referred to in the Preamble, nineteenth indent (see the proposal of the Netherlands, Sweden and Switzerland to include the clause "in accordance with the CTBT" in the test prohibition, ibid.).

53 See the answer of the Italian government (Mr. Giro, Vice Minister for Foreign Affairs) to the Commission on foreign and EU affairs of the Chamber of Deputies (III Commissione (Affari esteri e comunitari)), in Interrogazione a risposta immediata in Commissione 5/11829, 12 July 2017, available at: $<$ http:/aic.camera.it/aic/scheda.html?core=aic\&numero=5/11829\&ramo=CAMERA\&leg=17>; see also Permanent Representative of Switzerland to the Conference on Disarmament, "Explanation of vote", 7 July 2012, available at: <https://s3.amazonaws.com/unoda-web/wp-content/uploads/2017/07/Swiss-Explanation-ofVote2.pdf $>$. 
constitutes a move against the NPT regime, which risks undermining its effectiveness if not prejudicing its very survival. ${ }^{54}$ The Preamble to the TPNW reaffirms that "the full and effective implementation of the Treaty on the Non-Proliferation of Nuclear Weapons, which serves as the cornerstone of the nuclear disarmament and non-proliferation regime, has a vital role to play in promoting international peace and security". However, it is necessary to examine the realities of the relationship behind this rhetorical statement of principle. On the one hand, the TPNW might be viewed as fulfilling the ultimate purpose of the NPT, as clearly expressed first in its Preamble, ${ }^{55}$ and then in binding form in the text of one of its pillars, Article VI. On the other hand, there is no doubt that the aim of the drafters of the TPNW is to completely overcome the NPT regime as it is today, i.e. an international regime codifying a permanent situation of inequality and a deadlock of disarmament prospects, rather than the transitory arrangement suggested by a reading of its text.

From a normative point of view, the TPNW is not incompatible with the NPT, in a strict sense, as it does not prejudice the NPT's States Parties' obligations, but rather complements them by imposing additional, and onerous, obligations, in particular on the nuclear-weapon States Parties to the NPT, and on the non-nuclear-weapon States Parties that host nuclear weapons on their territories, as described above. ${ }^{56}$ As mentioned, these provisions prevail, in relation to States Parties to the TPNW, over any right that might be claimed under the NPT, and only with this broader meaning can one speak of an incompatibility. ${ }^{57}$ One could question whether the TPNW contradicts Article VII of the NPT, according to which the Treaty does not affect "the right of any group of States to conclude regional treaties in order to assure the total absence of nuclear weapons in their respective territories". Surely, the TPNW is not a "regional treaty", but, on the one hand Article VII is specifically intended to allow for the establishment of nuclear weapon free zones, and does not prohibit agreements with no regional focus; on the other hand, as already mentioned, the TPNW in fact intends to fulfil the NPT's declared final objective, and its negotiations were open to all States, without discrimination.

There are two further, and interconnected objections raised against the TPNW that we must briefly consider. The first relates to the discrimination under the Treaty between the majority of States Parties, which are merely subject to a "lenient" verification system (the comprehensive safeguards agreement), unless they are bound by stricter obligations under the NPT, and a minority (States still possessing, or having recently possessed nuclear weapons),

${ }^{54}$ See, e.g., US Mission to the United Nations, "Joint press statement from the permanent representatives to the United Nations of the United States, United Kingdom, and France following the adoption of a treaty banning nuclear weapons", 7 July 2017, available at: <https://usun.state.gov/remarks/7892>; North Atlantic Council Statement on the Treaty on the Prohibition of Nuclear Weapons, 20 September 2017, available at: < https://www.nato.int/cps/ua/natohq/news_146954.htm>.

${ }^{55} \mathrm{See}$, in particular, the eleventh indent: "Desiring to further the easing of international tension and the strengthening of trust between States in order to facilitate the cessation of the manufacture of nuclear weapons, the liquidation of all their existing stockpiles, and the elimination from national arsenals of nuclear weapons and the means of their delivery pursuant to a Treaty on general and complete disarmament under strict and effective international control".

${ }^{56}$ See, similarly, DUNWORTH, "The Treaty on the Prohibition of Nuclear Weapons", ASIL Insights, 31 October 2017, available at: <https://www.asil.org/insights/volume/21/issue/12/treaty-prohibition-nuclearweapons>; MASLEN, cit. supra note 43. See also JOYNER, "The Treaty on the Prohibition of Nuclear Weapons", EJIL: Talk!, 26 July 2017, available at: <https://www.ejiltalk.org/the-treaty-on-the-prohibition-of-nuclearweapons/>. An apparently different view is held by TREZZA, "The UN Nuclear Ban Treaty and the NPT: Challenges for Nuclear Disarmament", IAI Commentaries 17, 15 September 2017, available at: $<$ http://www.iai.it/it/pubblicazioni/un-nuclear-ban-treaty-and-npt-challenges-nuclear-disarmament $>$.

${ }^{57}$ See, among others, on norm conflicts between prohibitive norms, on one side, and permissive norms, on the other, VRANES, "The Definition of 'Norm Conflict' in International Law and Legal Theory", EJIL, 2006, p. $395 \mathrm{ff}$., especially p. $401 \mathrm{ff}$. 
which are subject to the much more pregnant Additional Protocol safeguards agreement. ${ }^{58}$ Some have raised fears (and this is the second objection) that States Parties to the NPT and subject to an Additional Protocol might be induced to denounce the NPT, while ratifying the TPNW, in order to reduce the scope of their verification obligations. Doing so would result in the collapse of the IAEA verification system, which would in fact mean the collapse of any effective check on respect for non-proliferation obligations. ${ }^{59}$

Maybe the fears of an easy trade between the onerous NPT and the indulgent TPNW are exaggerated, or at least premature. ${ }^{60}$ Nonetheless, the lack of agreement on extending to all States Parties the most accurate and all-encompassing verification mechanism is, in fact, unfortunate. Any disarmament agreement, if it aims to be effective, needs to rest on a strong verification system able to guarantee that no dangerous loopholes will open the way to any possible development and spread of prohibited items, and all the more so when the diversion of nuclear energy for military purposes is involved... The TPNW, as it is, is not able to provide such guarantees. All the same, one should take into account the fact that the Treaty does not and could not prejudice the application of the special regimes established by the UN Security Council with regard to specific countries, such as North Korea and Iran, or any additional regimes that the Council might implement in the future. One should also add that it is unfortunate that nuclear powers and their allies have been nearly totally absent from the Treaty negotiation process, as their active role might have generated pressure towards the adoption of, inter alia, a stronger verification apparatus, whatever the results of such a pressure would have been. ${ }^{61}$

\section{The ITALIAN POSITION}

As mentioned above, Italy is a non-nuclear-weapon State, which however hosts US nuclear weapons on its territory, as part of a nuclear sharing arrangement. Italy, therefore, unless it decided in the meantime to stop its nuclear sharing, would be directly affected by ratification of the TPNW, as the State would become bound to immediately proceed, under strict international verification, with the removal of the aforementioned weapons and their means of delivery from its territory. Differently from most nuclear powers, Italy participated in the conferences on the Humanitarian Impact of Nuclear Weapons of Oslo, Nayarit and Vienna, while maintaining a low profile. Participation was part of a strategy, consistently pursued by the Italian Government, to keep dialogue open with those civil society initiatives

${ }^{58}$ Various States proposed during the New York Conference an extension of Additional Protocols to all States parties to the TPNW: see, inter alia, Need for a verification mechanism at this stage for a treaty prohibiting nuclear weapons - Submitted by Chile, Sweden and Uganda, UN Doc. A/CONF.229/2017/WP.6 (2017); proposals of New Zealand, in Compilation of amendments, cit. supra note 53; comments of the Netherlands, in Compilation of amendments, cit. supra note 31. See also the criticisms expressed in Sweden, "Explanation of vote", 7 July 2017 available at: <https://s3.amazonaws.com/unoda-web/wpcontent/uploads/2017/07/170707-EoV-Sweden.pdf>; and Permanent Representative of Switzerland, cit. supra note 53. On the Italian government's criticisms see infra Section 9.

${ }^{59}$ See the proposal of Sweden to introduce a second paragraph into the article concerning the relationship with other agreements, stating that the treaty "shall not be cited as grounds for leaving the Treaty of NonProliferation", in Compilation of amendments, cit. supra, note 52, and the even stronger proposal of the Netherlands, to insert a second paragraph into draft Art. 15 (the current Art. 14, on ratification) providing that "[n]o State may establish its consent to be bound by this treaty unless it has previously established or establishes at the same time its consent to be bound by the NPT", in Compilation of amendments, cit. supra note 31 . See also US Mission to the United Nations, cit. supra note 54.

${ }^{60}$ On this point, see SosSAI, cit. supra note 41, p. 204.

61 See RONZITTI, "Armi nucleari: ONU discute se abolirle”, Affari internazionali, 26 March 2017, available at: $<$ http://www.affarinternazionali.it/2017/03/armi-nucleari-onu-discute-abolirle/>. 
and NGOs engaged in pursuing the goal of complete nuclear disarmament. Italy decided, however, in consonance with all the official and non-official nuclear powers and with almost all the "nuclear umbrella" States (except the Netherlands) not to take part in the UN Conference convened to draft and adopt the TPNW. ${ }^{62}$ The Government's position was subjected to debate in Parliament at the time of the adoption of the UN General Assembly resolution convening the abovementioned Conference, ${ }^{63}$ at the time of the adoption of the Treaty, and at the time of its opening for signature. In particular, on 19 September 2017, the Chamber of Deputies adopted a majority motion engaging the Government to, first, continue to pursue the objective of a nuclear weapons-free world, through a progressive approach to disarmament, recognizing the centrality of the NPT, and considering the possibility to accede to the TPNW, in conformity with NATO engagements and with the orientation of its allies; and, second, to promote, together with its partners, the universality of the NPT, the entry into force of the CTBT, the conclusion of a Fissile Material Cut-off Treaty (FMCT), the strengthening and extension of NWFZs, especially in the Middle East, and other transparency and confidence-building measures able to lead to a general disarmament. ${ }^{64}$ The motion was accepted by the Government.

Although the motion is certainly indicative of the Italian Parliament's sensitivity, shared by other parliaments as well, towards the issue of nuclear disarmament, and even of openness to favourably consider the future universalisation of the TPNW, this should not lead to the conclusion that the Government has modified its position. The motion is formulated in extremely cautious language, and it merely directs the Government to consider future participation in the Treaty, "in conformity with the orientation of its allies". By accepting this request the Government is, in reality, confirming its rejection of the Treaty rebus sic stantibus, i.e. until some fundamental change of circumstances, such as the modification of the position of all NATO countries, and specifically of the nuclear-weapon States among them, could lead it to reopen the issue. The Government's position has always been the same, as expressed various times before Parliament in recent months: Italy pursues a progressive and inclusive path towards nuclear disarmament, through a series of transparent and verifiable steps such as those mentioned in the second part of the motion; it strongly affirms the centrality of the NPT; it adheres to NATO's deterrence doctrine reaffirmed in Warsaw in $2016 .{ }^{65}$ Italy has not participated in the UN Conference, considering it to be a divisive move on an issue that would require the full involvement of all military nuclear powers. The Government has also criticized the text of the TPNW, expressing doubts that it could ever lead to an irreversible, transparent and verifiable nuclear disarmament, in particular due to its lack of general acceptance of the highest standards of IAEA verification, and to the lack of verification mechanisms in relation to nuclear tests, which, it claims, threaten to compromise

62 Notwithstanding the invitation of the European Parliament to EU member States "to participate constructively in its proceedings", in Resolution of 27 October 2016 on nuclear security and non-proliferation (2016/2936(RSP)), available at: <http://www.europarl.europa.eu/sides/getDoc.do?pubRef=//EP//TEXT+TA+P8-TA-2016-0424+0+DOC+XML+V0//EN\&language=EN $>$. On the divided paths followed by EU member States in relation to the New York Conference and Treaty see, among others, RONZITTI, cit. supra note 61, and TREZZA, cit. supra note 56.

${ }^{63}$ On the Italian vote, see supra note 3.

${ }^{64}$ See Italian Chamber of Deputies, Atto Camera - Mozione 1/01699, 19 September 2017, available at: $<$ http://aic.camera.it/aic/query.html $>$.

65 See NATO, Warsaw Summit Communiqué - Issued by the Heads of State and Government participating in the meeting of the North Atlantic Council in Warsaw 8-9 July 2016, 9 July 2016, available at: $<$ https://www.nato.int/cps/en/natohq/official_texts_133169.htm>. 
both the NPT and the CTBT regimes. For the above reasons the Italian Government does not intend to sign the TPNW. ${ }^{66}$

Therefore, the Italian position seems consonant with the stance expressed by the North Atlantic Council, including Italy, on 20 September 2017. According to the NATO Council, the TPNW "is at odds with the existing non-proliferation and disarmament architecture", and "risks undermining the NPT [...], and the IAEA Safeguards regime which supports it". The NATO countries, furthermore, assure that there will be no change in their legal obligations "with respect to nuclear weapons", and refuse "any argument that this treaty reflects or in any way contributes to the development of customary international law", 67

\section{PROSPECTS FOR ENTRY INTO FORCE AND UNIVERSALISATION}

By mid-May 2018, nearly eight months after it opened for signature, the TPNW had been signed by 58 States, and ratified by nine: Austria, Cuba, Guyana, Mexico, Palau, Thailand, Venezuela, the Holy See, and the State of Palestine. ${ }^{68}$ According to Article 15, the Treaty is to enter into force 90 days after the fiftieth ratification or acceptance: differently from the NPT, which required ratification by the USA, the UK and the USSR, designated as its depositary governments (in this case the depositary is the UN Secretary-General: Article 19), and from the CTBT, which requires ratification from a list of 44 States (which explains why the treaty is not yet in force), the drafters of the TPNW decided to facilitate its entry into force by not requiring acceptance from any particular State. This means that the Treaty may enter into force even without the participation of any nuclear-weapon State. Given that the Treaty, as already recalled, was adopted with positive votes by 122 States, reaching the goal should not be overly difficult, unless other external factors intervene to hinder the process. For the moment, the number of signatures, and even more so of ratifications, is rather low. But it is too early to make any reliable forecasts. One can only note that delays in signing and ratifying multilateral treaties are common, especially in the disarmament and arms control field. Nonetheless, it is notable that a controversial treaty, and one that is still far from being universal, such as the CMC, had been signed by 94 States by the day after its opening for signature, although it required over a year before reaching the thirty ratifications necessary for its entry into force. In the case of the TPNW, the path seems rather slow, for the moment, especially taking into account that the ratification process should not prove any onerous for any of the potential candidates today (presumably all non-nuclear-weapon States already parties to the NPT), as it shall not require the elimination of any arsenals or the subjection to any new verification mechanism. As for the political price to pay, this is obviously a different matter.

Be that as it may, the entry into force of the TPNW, if and whenever it will take place, will not produce any direct consequences for nuclear disarmament, as it is foreseeable that no nuclear-weapon State will accede to the Treaty in the near future. In fact, a multilateral agreement such as the TPNW requires universal participation in order to be effective, even more than the NPT does. The NPT, notwithstanding its flaws and its failures, has produced important results over the years in terms of opposition to the proliferation of nuclear weapons, without having ever reached complete universality. By contrast, a nuclear disarmament agreement will never work unless all nuclear-weapon States, official and non-official, engage

${ }^{66}$ See the answer of the Italian Government, cit. supra note 53. According to SoSSAI, cit. supra note 41, p. 200, it is surprising that the government does not refer in its statements to the issue of compatibility between its NATO engagements and the TPNW's obligations.

${ }^{67}$ See North Atlantic Council Statement, cit. supra note 54.

${ }^{68}$ The status of the Treaty is available at: $<$ http://disarmament.un.org/treaties/t/tpnw $>$. 
in disarmament at the same time; in particular, the big powers are the least likely of all to give up nuclear weapons, unless they can trust that their potential enemies are doing the same. It is, therefore, no wonder that Article 12 explicitly indicates the goal of universality. At the moment, this seems a distant prospect.

Nonetheless, it is foreseeable that the entry into force of the Treaty, and subsequent growth in the number of States Parties, would produce consequences. Even without envisaging that this process might induce a flight from the NPT into the new treaty and thus effect the collapse of the non-proliferation regime, as NATO countries fear, the TPNW would attract more and more attention from international actors, including civil society organizations. Its meetings of States Parties, to be convened every two years, entrusted by Article 8 with the task of making decisions "in respect of any matter with regard to the application or implementation" of the TPNW and "on further measures for nuclear disarmament", and review conferences, to be held five years after entry into force and every six years thereafter, ${ }^{69}$ will exercise competences to a large extent overlapping with those of NPT Review Conferences, although real decisions will remain the prerogative of the latter as far as nuclear-weapon States will be concentrated in them. But this process, thanks in part to intense lobbying by representatives of international public opinion, might exert strong pressure on nuclear-weapon States in order to induce them to finally undertake concrete and decisive steps on the way towards nuclear disarmament. They might be induced, inter alia, to exercise pressure, in turn, on the States Parties to the TPNW, in order to convince them to adopt amendments to the Treaty to accommodate their own goals, which could ultimately facilitate their acceptance of the Treaty. ${ }^{70}$ These are mere speculations that may be belied by reality. The point is that, once a process has started, it is difficult to foresee where it will lead. This will be decided, in the end, not by non-nuclear-weapon States, but rather by the nuclearweapon ones. It has to be hoped that, even if nuclear-weapon States and their allies will not be motivated by faith in the TPNW, at least their fear, in the face of the potential dismantlement of the non-proliferation architecture, could work, in the long term, as a positive stimulus toward their decisive engagement in disarmament.

${ }^{69}$ See Art. 8(4): the conferences shall "review the operation of the Treaty and the progress in achieving the purposes of the Treaty".

${ }^{70}$ Amendments to the TPNW are regulated by Art. 10, which provides for them to be adopted by a meeting of States parties or by a review conference. See the final considerations of JOYNER, cit. supra note 56. 